\title{
Consuming the past into the present: The case of the lberians (Valencia, Spain)
}

\author{
Beatriz Santamarina $^{1 *}$ (D) and Tono Vizcaíno ${ }^{2}$ \\ ${ }^{1}$ Department of Sociology and Social Anthropology, Universidad de Valencia, Spain \\ ${ }^{2}$ Independent Scholar \\ *Corresponding author. Email: beatriz.santamarina@uv.es
}

\begin{abstract}
In this article, we aim to focus on how the Iberian past (sixth century to the first century $\mathrm{BC}$ ) has been used both to shape identities and to produce values in the marketplace and how the triad of the past, authenticity, and tradition is key in the commodification of the Iberian world. To do so, we will examine developments in the village of Moixent (Valencia, Spain). In this town, the Iberians and their archaeological remains are presented as the protagonists of the area, accompanied by several "heritage stratifications." Through case studies of family-run wineries, we analyze the process of symbolic appropriation of the Iberians in the local wine sector and its confluence with cultural tourism as well as how it has led to the development of territorial branding based on the past.
\end{abstract}

Keywords: cultural heritage; past; authenticity; commodification; heritage; brands; Iberians

\section{Introduction}

In 2000, Celler del Roure, a small family-run winery that opened in 1996 in the village of Moixent (Valencia, Spain) launched its wine named Les Alcusses. Moixent has a strong connection with its Iberian past. It is home to one of the most salient archaeological sites in the Valencian community, La Bastida de les Alcusses, where the so-called "Moixent Warrior" was found. Along with the Lady of Elche, this small bronze figure, dating from the fourth century вс, has become one of the foremost icons of Iberian culture in the Valencian region. The site itself is a landmark in Valencian archaeology, given the wealth of its remains and the quality of the research performed during the first excavations, which were carried out between 1928 and 1931 by the Prehistoric Research Service (Servicio de Investigación Prehistórica [SIP]). ${ }^{1}$ It was so well known during that time that the press in 1928 defined it, significantly, as "the new Pompeii." In 1931, the ruins were listed in Spain as a historic and artistic site, which soon led to their heritagization.

But let us go back to 2000. The wine was persuasively named Les Alcusses, and its label design displayed fragments of an Iberian text found at the site, reproducing the original script.

\footnotetext{
${ }^{1}$ The Servicio de Investigación Prehistórica was created in 1927 jointly with the Prehistory Museum of Valencia. The excavations were carried out in collaboration with the recently founded Archeology Laboratory at the University of Valencia, founded in 1921. See Bonet and Vives-Ferrándiz 2011.

2 Bonet and Vives-Ferrándiz 2011, 12.

(c) The Author(s), 2021. Published by Cambridge University Press. This is an Open Access article, distributed under the terms of the Creative Commons Attribution licence (http://creativecommons.org/licenses/by/4.0/), which permits unrestricted re-use, distribution, and reproduction in any medium, provided the original work is properly cited.
} 
The award-winning Spanish graphic designer Dani Nebot played with the elements that his clients aimed to convey: the memory and tradition of winemaking in the area. On the winery's website, they described this wine as a particular synthesis of "our land and our history." Robert Parker, one of the most influential wine critics in the world, included Les Alcusses in his list that same year, rapidly boosting its popularity. The wine's strongest point, aside from its quality, was being immediately identifiable by its label. The strategy was clearly stated: the (Iberian) past can be consumed (drunk). The use of Iberian, a paleo-Hispanic language, acted as a key element. The receiver was unable to translate the text but could read the message. There was no need to know the language: the more distant and stranger it seemed, the easier it became to recreate countless attributes. A past associated with authenticity (certified by the use of script $)^{3}$ and artisanal production (reinforced by the wine's name) gave the product a unique identity. Together, the label and the name acted as a form of metonymic restitution, conveying highly regarded values such as the past, authenticity, and tradition.

Celler del Roure's strategy proved to be right on target. The idea was not only to offer an excellent product that was capable of competing in the wine market but also to create an image. The media described this relationship as a "memorable pairing of wine and design." Over the past decades, the wine industry has been growing at a good rate, while, in the last five years, its consumption has increased in Spain. ${ }^{5}$ According to the data provided by the International Organisation of Vine and Wine (OIV), Spain has the largest acreage of vineyards and is the world leader in exports in terms of volume. ${ }^{6}$ This growth has driven investment in innovation and revolutionized the designs for bottles, names, and labels. Graphic design has always been an important element in the marketing of wines through their labels, shaping a wine's identity and branding its place of origin, yet never before have the ties between the two been so close. ${ }^{7}$ Among other demands, the requirements of cognitive capitalism or of capitalism without capital have led stakeholders ${ }^{8}$ to aggregate intangible values so as to provide products with a competitive edge. ${ }^{9}$ According to this logic, we can interpret Celler del Roure's strategy and the use of the past as a marketing strategy.

Ever since the late twentieth century, the use of the past has gradually been gaining relevance. Some authors suggest that we are witnessing an obsession with the past and tradition and craving authenticity during a period marked by longing and nostalgia. ${ }^{10}$ The demand for heritage in post-Fordist capitalism and the need to think of ourselves and find certainties in an unleashed, liquid, or unmoored world, full of fractured identities and fragmented meta-narratives, are in fact the two sides of the same coin. ${ }^{11}$ And, today, both of these factors allow us to approach how we bridge the gap between our past and our present.

\footnotetext{
${ }^{3}$ The concept of "authentic" is related to a genuine character and to the idea of being true or faithful to the origins. As have been largely argued, authenticity is a key element in legitimizing the past and traditions (Spooner 1988; MacCannell 1999). Today, the market for intangibles is linked to the search of authenticity within neoliberal dynamics (Heinich 2009; MacDonald 2013). We will come back to this later in the article.

${ }^{4}$ Eugenio Viñas, "Dani Nebot y Celler del Roure: el maridaje memorable entre diseño y vino," CulturPlaza, 2016, https://valenciaplaza.com/dani-nebot-y-celler-del-roure-el-maridaje-memorable-entre-diseno-y-vino (accessed 8 March 2021).

${ }^{5}$ Fernández 2019.

${ }^{6}$ See the "Statistical Report on World Vitiviniculture," 2019, https://www.oiv.int/public/medias/6782/oiv2019-statistical-report-on-world-vitiviniculture.pdf (accessed 8 March 2021).

${ }^{7}$ Nogué and San Eugenio 2017; Alcaraz and Medina 2019; Fernández 2019.

${ }^{8}$ Egloff 2006.

${ }^{9}$ Boltanski and Chiapello 2002; Scott 2014; Haskel and Westlake 2017.

${ }^{10}$ Boym 2001; Herzfeld 2005; MacDonald 2013; Frigolé 2014; Santamarina and Moncusí 2015; Angé and Berliner 2016; Bauman 2017; Korstanje 2019.

11 Giddens 1990; Bauman 1991; Berger and Luckman 1995; Beck and Beck-Gernsheim 2003; Hall 2010.
} 
In this article, we aim to focus on how the Iberian past was used both to shape identities and to produce values in the marketplace and how the triad of the past, authenticity, and tradition is key in the commodification of the Iberian world. To do so, we will examine the developments in the village of Moixent. In this town, the Iberians are presented as the protagonists of the area, accompanied by several "heritage stratifications." This analysis is part of a broader investigation of the Iberian past in the Valencian collective imagination. Most of the fieldwork was performed between 2010 and 2014 and then completed with additional fieldwork in 2020 . The techniques used in this research included participant observation (archaeological sites and Iberian re-enactments), interviews with key sources (experts, technical staff, local residents, and visitors), and the analysis of media content, legislation, official documents, textbooks, tourist pamphlets, websites, and consumer products and services.

\section{The Iberians and their political instrumentalization}

When we speak of Iberian culture, we are referring to the culture complex that developed from the sixth century to the first century $\mathrm{BC}$ along the coastal area that spreads from southern France to the Guadalquivir River in Andalusia. Given the vast chronological and territorial scope of Iberian influence, it makes no sense to think in terms of a homogeneous, static reality, and, in recent years, this fact has driven research to view Iberian culture as a plural concept. Although there are certain common patterns that apply from north to south, there are also a large number of nuances that vary according to each territory and period. Archaeological researchers have observed these differences by contrasting material evidence, historical sources, and theoretical paradigms since the late twentieth century. ${ }^{12}$ Over the course of history, the corpus of historiography about Iberian culture has been based on the descriptions that the Greeks and Romans made of the Iberians in ancient times. Consequently, from the sixteenth century on, this historiography has perpetuated clichés and prejudices based on the civilized/savage dichotomy. ${ }^{13}$ In addition to this bias, there is political significance wherein Iberian culture is viewed as the seed of the Spanish spirit and presented as the oldest culture with a name of its own, which has spread widely enough across the territory to provide the basis for a patriotic essence. ${ }^{14}$ It also had the added value of building a direct connection between the ethnonym (Iberian) and the toponym (Iberian Peninsula).

It is hardly surprising that the Iberian past has been used by differing political and identity-related forces that have placed archaeology at the service of their respective interests. From the nineteenth century on, Spanish nationalism built a monolithic image of Iberian identity in keeping with the idea of a nation, to the extent that it turned the Iberian history into the Spanish state's common past, even despite archaeological evidence indicating the exact opposite. ${ }^{15}$ The process of heritagizing the Iberians began in the early twentieth century in the context of the earliest legislation on national heritage and the archaeological excavations at Iberian sites. The Spanish Royal Decree-Law on National Artistic and Archaeological Treasury (1926), which was highly progressive legislation for its time,${ }^{16}$ led to the declaration of four Iberian ruins in Valencia as historic and artistic sites.

If we focus on the Valencian context, there was a revival of the vernacular in cultural terms beginning in the mid-nineteenth century. This movement, known as the Renaixença, set the foundations for the regionalist Valencian imaginary and viewed the Iberian past as

\footnotetext{
${ }^{12}$ Ruiz and Molinos 1998; González and Rueda 2010; Aranegui 2012.

13 Arce and Olmos 1991; Cruz 2002.

${ }^{14}$ Wulff 2003.

${ }^{15}$ Arce and Olmos 1991; Díaz-Andreu 1995.

${ }^{16}$ Gómez 2016.
} 
an exclusive cornerstone of its identity. Using the descriptions in ancient writings and the major findings that were taking place at the time, the intellectuals of the Renaixença built the notion of Iberian-Valencian singularity. This view certified "glorious" origins and all sorts of cultural, territorial, and even characterological continuities. ${ }^{17}$ In the first decade of the twentieth century, the foundations were laid for an incipient political Valencianism in which Iberian identity was used to set forth claims regarding the Iberian language and race. ${ }^{18}$ The expectations generated by this narrative, which could have clashed with the monolithic conception of the state, were dashed by the Civil War (1936-39) and the Franco dictatorship (1939-75).

During the Franco era, the Iberians were used for the construction of a national identity, taking root in the Spanish collective imagination, with the exception of the first few years, when Falange Española tightened its bonds with Nazi Germany through Celtic culture. ${ }^{19}$ This discourse was increasingly legitimized by the recovery of the Lady of Elche, which was held at the Musée du Louvre until 1941, by the renewed value attached to iconic figures such as the Moixent Warrior, and by the archaeological findings coming primarily from Valencia. All these factors contributed to the notion of the Iberian-Valencian singularity constituting a commendable achievement of Spanish history, and Valencian regionalism was put at the service of the state with support from Valencian archaeological institutions. ${ }^{20}$

The dictatorship's iron grip on the past was broken by the advent of democracy (1975) and the introduction of a political structure of autonomous communities in Spain (1978). ${ }^{21}$ Within the process of political and territorial reorganization, each autonomous community sought to define its identity by appealing to the past. Within this context, the interpretation of Iberianism was an ally for the state, allowing it to use history and archaeology to legitimize a common framework with multiple cultural expressions. The autonomous communities with Iberian vestiges (Catalonia, Aragon, the Valencian community, CastillaLa Mancha, Murcia, and Andalusia) found different ways of approaching this past. ${ }^{22}$

In the case of Valencia, the regionalist approach, compatible with Spanish nationalism, prevailed throughout the twentieth century. With the advent of democracy, the opportunity of having institutions for self-government led to a conflict over the Iberian past. The triumph of the regionalist narrative and its consolidation in power ensured the persistence of the Iberian identity. During the 1980s and 1990s, the Valencian administration emphasized the value of the Iberian world, allocating considerable public funding to this aim. Its heritage process followed the classic model involving museumification and regulatory protection, although it was also supported with other resources, such as a large number of general readership publications, textbooks, and documentaries broadcast on the autonomous community's public television channel. Nine new archaeological museums opened during this period, complementing another nine that had been founded in the course of the century. ${ }^{23}$

As far as legislation is concerned, in 1991, when competences in the area of culture were transferred to the autonomous communities and despite not yet having its own heritage law, the Valencian administration began to declare some sites to be sites of cultural interest (bienes de interés cultural [BIC]), the highest protection status in Spain..$^{24}$ When the Valencian

\footnotetext{
${ }^{17}$ Aranegui 2012; Vizcaíno 2016a, 2018.

${ }^{18}$ Archilés 2006; Vizcaíno 2016b.

19 Wulff 2003; Ruiz, Sánchez, and Bellón 2002.

${ }^{20}$ Vizcaíno 2016b.

${ }^{21}$ The Spanish Constitution of 1978 established the institutional organization of autonomous communities in Spain.

${ }^{22}$ Rivière 2000; Vizcaíno 2018.

${ }^{23}$ Archilés 2006; Azuar 2013; Vizcaíno 2018.

${ }^{24}$ In order to do so, it applied the Law of Spanish Historical Heritage (1985).
} 
Cultural Heritage Law (1998) went into force, heritage asset declarations increased, coinciding with the surge of heritage listings all over the world. As for Iberian archaeological sites, all BICs recognized by the Spanish legislation were listed as Valencian heritage assets from that moment on. Since the law was passed, the province of Valencia alone has 17 BICs with Iberian vestiges. This heritagization process not only fulfills a need for protection but also provides a new market logic. After the site in a small town was listed as a BIC in 2017, the mayor declared: "This listing places us on the map of Spanish tourism."

His statement confronts us with a new reality. In the twenty-first century, attention toward the Iberian past has undergone a Copernican revolution: from the desire to construct the notion of an Iberian-Valencian singularity to placing the accent on the market. Above and beyond efforts aimed at conservation, the fact is that Iberian heritage has been increasingly promoted according to new market logic. This shift is manifested in various forms of "Iberian consumption." 25 The expansion of the creative economy and the development of late capitalism have opened up the realm of heritage to the market. ${ }^{26}$

\section{Marketing the Iberians}

The Iberians, viewed as a whole and supported by the academics, serve a key purpose in the present: either as political instruments for validating identity-related aims or as market products for consuming the past. Their early heritagization attests to the role they played in patriotic mapping and in the construction of national identities. ${ }^{27}$ Aside from their political uses, the application of the image of the Iberians to local products has been recurrent throughout the Valencian community, where they have been used as advertising claims given their potential attributes. ${ }^{28}$

The Iberian world recalls a series of qualities that are on the rise: the past, authenticity, and tradition. This triad, condensed into the concept of heritage, has a powerful appeal for the neoliberal economy. The past acts as the bearer of an "original truth" rooted in various disciplines ${ }^{29}$ and appears as a guarantor of tradition. In turn, tradition, endowed with numerous virtues such as immutability, legacy, and conservation, evokes not only the uses of a place linked to a pre-Fordist time but also the notions of the rustic and the wild, viewed as being closer to nature. ${ }^{30}$ The association of authenticity with purity allows us to interpret the origin as true. ${ }^{31}$ From this perspective, the authenticity/past/tradition trinity becomes a vehicle of extraordinarily efficient symbolic value, insofar as, in a continuum of sorts, it is able to transfer its qualities to the product being promoted. ${ }^{32}$ In many cases, the introduction of intangible value has led to a competitive edge being gained through this triad, which in fact encapsulates the new neoliberal heritage models. ${ }^{33}$

When heritage is turned into capital, it operates efficiently in tourism strategies and product marketing. The tertiarization of the economy, heritage inflation, and the growth and diversification of tourism have advanced in parallel. Today, tourism and heritage are perfectly paired. ${ }^{34}$ The heritage factory adapts easily to the demands of a market that is

\footnotetext{
${ }^{25}$ Mata and Vizcaíno 2013.

${ }^{26}$ Del Mármol and Santamarina 2019.

${ }^{27}$ Anderson 1983; Poulot 2006.

${ }^{28}$ Vives-Ferrándiz 2006; Vizcaíno 2016b, 2018.

${ }^{29}$ Smith 2004; Santamarina and Beltran 2016.

${ }^{30}$ Hobsbawm and Ranger 1983; Lowenthal 1985; Frigolé 2007, 2010.

31 Jokilehto 2006; Benjamin 2007; Bendix 2009; Holtorf 2013; Frigolé 2014.

32 Del Mármol and Estrada 2018; Jiménez-Esquinas and Sánchez-Carretero 2018.

33 Santamarina and Del Mármol 2020.

34 Jeudy 2001; Baram and Rowan 2004; Heinich 2009; Timothy 2011, 2018; Korstanje 2012.
} 
eager to consume authenticity, the past, and tradition. ${ }^{35}$ Its power of attraction is clearly visible in the marketing of products that seek to be associated with great civilizations. ${ }^{36}$ Heritage is presented as a powerful economic resource, given its ability to fulfill the demand, configuring new geographies for cultural tourism and constituting the leading segment of the tourism industry. ${ }^{37}$ Thus, it has created the heritage surge whereby cultural sites have become the new oil wells ${ }^{38}$ and managing the brand has become the focus rather than the heritage asset per se. ${ }^{39}$ The tourism industry has renewed itself by breaking its own records, offering new forms of tourism involving multiple experiences. ${ }^{40}$

With regard to the Iberians, over the past 20 years, their use as an economic and heritage asset has increased; tourism strategies and cultural products have turned them into a vehicle for rural development. In all of these cases, a stereotyped Iberian past is presented, with values and attributes that are easily identifiable for consumers (strength, ruggedness, purity, bravery, resistance). These qualities are suggested through icons (the Moixent Warrior) and the names of characters (Edecon) and places (Kelin). However, we also find the term "Iberian" used as an ethnonym and an adjective (in Spanish, Ibero and Ibérico respectively) or an over-signification that simultaneously suggests the name and the image (as in the case of the wine mentioned earlier, Les Alcusses).

In our case study, La Bastida has become a powerful landmark in Valencia, with the Moixent Warrior encapsulating Iberian culture. Its image on the cover of the district's tourist guides, which are published by the local government, bear witness to its importance as an icon. Several inland villages in Valencia have used their Iberian heritage as a brand, enabling the reclassification of their territory (symbolic, political, economic, and legal). For example, the tourist brochures for Camporrobles" ${ }^{41}$ feature the slogan "Experience Authenticity" and "An Age-Old Culture, Landscapes Full of Life"; the ones for Ayora offer a diversified tourism package in which archaeology, nature, and gastronomy are presented under the heading of "Iberian Ayora." 42

Today, tourism is an important asset for rural municipalities outside the mainstream tourist circuits and global economic centers. ${ }^{43}$ The new rules for the market have forced them to reconsider their production strategies, offering consumers a variety of experiences to fulfill their demand. The development of archaeological sites has allowed for highly successful new forms of cultural tourism to emerge, based on experiential activities. The open days at La Bastida in Moixent or Iberfesta in Olocau ${ }^{44}$ are just a couple of examples of a recurrent phenomenon in towns with Iberian vestiges. In this model, workshops, activities, and gastronomy converge against the backdrop of a reenactment of the Iberians' everyday lives. ${ }^{45}$

Rural tourism has also used the Iberian past to evoke qualities linked to physical effortin instances such as the Outlet Running Trail in Moixent or the Trail Moixent. The former is a

\footnotetext{
${ }^{35}$ Davallon 2010; Del Marmól and Estrada 2018.

${ }^{36}$ Kristiansen 1992; Ortiz 2001; Ruiz, Sánchez, and Bellón 2002; Hamilakis 2003; Schnitzler and Schnitzler 2006; Yalouri 2014; Melotti 2017.

${ }^{37}$ Richards 2000, 2014; World Tourism Organization 2018; Espeso-Molinero 2019.

${ }^{38}$ Richards 2019.

${ }^{39}$ Meskell 2014.

${ }^{40}$ Espeso-Molinero 2016; World Tourism Organization 2019.

${ }^{41}$ Inland municipality, population 1,195. Instituto Nacional de Estadística, "Datos por Temas," 2019, https:// www.ine.es/ (accessed 8 March 2021).

${ }^{42}$ Inland municipality, population 5,342, surrounded by fairly high mountains. Instituto Nacional de Estadística, "Datos por Temas."

${ }^{43}$ Roigé and Frigolé 2010; Del Mármol, Celigueta, and Vaccaro 2018.

${ }^{44}$ Inland municipality, population 840. Instituto Nacional de Estadística, "Datos por Temas."

45 Pérez and Jardón 2011; Mata and Vizcaíno 2013; Ripollés et al. 2016.
} 
race promoted with the slogan "Unleash the Warrior Inside You," and the course is called "The Warrior's Trail." The latter is a cycling race that also uses the image of the warrior. Paradoxically, they are advertised in English and presented with icons and discourses from the ancient world. ${ }^{46}$ Last of all-although we will return to the many varieties of tourism later in this article-we find the Valencia Iberian Route, which spans the 10 municipalities containing the foremost Iberian sites in the province of Valencia. ${ }^{47}$ This cultural product is particularly significant because it is a public initiative, coordinated by the Prehistory Museum of Valencia, that reveals the desire to validate and confer authenticity to the area covered by the route. However, as one of its staff members has acknowledged, "the project arose from the museum's experience at the sites where archaeological digs were underway, ... and it became apparent that there was a very interesting, powerful complementarity in terms of tourism." Accordingly, this example is paradigmatic of the effort to attribute value to heritage assets for the purpose of rural development ${ }^{48}$ and the importance of heritage brand management.

\section{The lberians as a brand}

Let us go back to the beginning of this article, where we described how a family-run winery had launched a wine for which it used territorial branding based on the Iberian past. The choice was hardly arbitrary: first of all, because the winery was a pioneer in using the Iberian past in the area, and, second, because the La Bastida site has shaped, and been associated with, the landscape of the so-called Terres dels Alforins (Land of the Alforins), where a variety of strategies overlap in a heritage stratification of sorts aimed at launching cultural products and services. We use the term "heritage stratification" to designate the use of a series of practices that are implemented to highlight the different heritage dimensions contained in a single object, subject, or territory, with the aim of building an over-arching heritage.

In Moixent, ${ }^{49}$ La Bastida monopolizes the heritage offering. Long after the SIP archaeological excavations that took place in 1928-31, the site was considerably modified in the 1970s: on the occasion of the SIP's fiftieth anniversary, remains were consolidated, and accessibility was improved. These efforts laid the groundwork for a more ambitious venture in the 1990s. The site's optimal conditions (status as a historic-artistic site, a fairly large excavated area, abundant documentation, and an unchanged agricultural landscape) led the SIP and the Prehistory Museum of Valencia to undertake a project that involved researching, preserving, and promoting the remains in panels, brochures, guided tours, educational workshops, and even the reconstruction of an Iberian house. ${ }^{50}$ The project was, and continues to be, supported by the Moixent Town Council, which viewed the site as an asset that allowed them to distinguish themselves from other municipalities. In fact, Moixent has other heritage assets as well, aside from the Municipal Archaeological Museum, which is closely linked to La Bastida, including two examples of schematic cave paintings that were added to the World Heritage List in 1998 (Abrigo de Gontrán and Abrigo de la Penya); ${ }^{51}$ two

\footnotetext{
${ }^{46}$ This marketing strategy is related to an increasingly global/international focus, which not only uses a foreign language but also refers to an added ideological value that positions it as up to date (and even more so in a rural context).

${ }^{47}$ Diputació de València, Ruta dels Ibers, http://www.rutadelsibersvalencia.org/es (accessed 8 March 2021).

${ }^{48}$ Bonet, Vives-Ferrándiz, and Caruana 2005; Ferrer, Mata, and Vives-Ferrándiz 2007; Ferrer and Vives-Ferrándiz 2014.

${ }^{49}$ Inland municipality, population 4,302, located in the district of La Costera. Instituto Nacional de Estadística, "Datos por Temas."

${ }^{50}$ Bonet and Vives-Ferrándiz 2011; Fortea and Ripollés 2011.

${ }^{51}$ As part of the "Rock Art of the Mediterranean Basin on the Iberian Peninsula."
} 
other assets that were listed as BICs in 2011 (Coveta de les Cabres and Barranc de les Coves); an example of eighteenth-century hydraulic engineering that was listed as a BIC in 2005 (the Presa del Bosquet dam, presented as "a natural and heritage jewel" by the town council and the tourism companies); and an architectural complex from the Almohad period (Torre dels Coloms). However, La Bastida truly is the celebrity, even beyond the town limits. In less than 20 years, it has doubled its number of visitors-up from 8,562 in 2000 to 14,822 in 2018-thus appearing as the main highlight in the local tourism offering, be it cultural, rural, sports, or wine related. ${ }^{52}$

In the wake of the excellent reception and success of this Iberian "offering," other heritage initiatives have been set in motion, leading to a highly productive symbiosis. Moixent is located in the southwest of the province of Valencia, in one of the region's main winemaking areas: its wines boast the Valencia certificate of origin. Three villages in the area (Moixent, Fontanars dels Alforins, and La Font de la Figuera) form a triangle that the winemakers have named Terres dels Alforins. Although the official certificate of origin is Valencia, ${ }^{53}$ the 11 wineries within the area have promoted the new name, which does not correspond to any particular administrative division. The winemakers' association known as Societat de Viticultors i Productors de Terres dels Alforins launched the brand in an attempt to identify the area as a cultural landscape in which the local wine-related agriculture would be interpreted as a historical legacy. Not surprisingly, the name chosen was Alforins, an Arabic toponym (al-huri) that means "granary" and refers to the richness of the land, as a clear reference to the past. Its website, Terres dels Alforins. Paisatge de vins (Land of the Alforins: Landscape of Wines), ${ }^{54}$ provides information on the wineries and a broad range of tourism highlights (villages, nature, history, gastronomy, and so on). It is a clear example of heritage activation promoted by groups within the agricultural sector. However, we could also consider it to be a way of promoting inland tourism associated with experiencing the place, the unique character of its land, and its identity. ${ }^{55}$ The public administration was involved in this process, as one of the interviewed civil servants noted: "We participated in the strategic planning work for Terres dels Alforins. ... The three municipalities were involved ... and we were there as La Bastida de les Alcusses, as the site."

Today, given the need to diversify the Valencian tourist business beyond the seaside holiday model, the Terres dels Alforins wine tourism route has been included in the offerings. This kind of association between a cultural product and the rural development of winemaking areas has been growing constantly over the past few years in Spain. ${ }^{56}$ Enotourism is yet another area within agro-tourism, supported by the heritagization of the cultural sphere related to wine. It has become especially relevant, as is apparent from the fact that the United Nations Educational, Scientific and Cultural Organization (UNESCO) listed the "Traditional agricultural practice of cultivating the 'vite ad alberello' (headtrained bush vines) of the community of Pantelleria" as intangible cultural heritage (ICH) in 2014 and the "Champagne Hillsides, Houses and Cellars" as an object of World Heritage in 2015. Thus, the heritagization of wine growing has materialized along two interconnected paths. On the one hand, "the heritage label is applied to food products in the form of certificates of origin." 57 The certificates of origin serve a symbolic purpose that generates marketing strategies based on certification, increasing a product's value by appropriating

\footnotetext{
${ }^{52}$ Data provided by the Prehistory Museum of Valencia.

53 “Denominación de Origen Valencia," https://www.dovalencia.info/ (accessed 8 March 2021).

${ }^{54}$ Terres dels Alforins: Paisatge de vins," Terres dels Alforins, http://terresdelsalforins.com/index.php/es/ (accessed 8 March 2021).

${ }^{55}$ Marlowe and Lee 2018; Picard, Nascimento, and Loloum 2018; Ilak, Damijanić, and Šergo 2019.

${ }^{56}$ Molinero and Cascos 2017; Fernández 2019.

${ }^{57}$ Del Mármol and Estrada 2018, 231.
} 
the features of a place and then transferring them to the products. ${ }^{58}$ The development of brands associated with quality and origin often involves promoting production practices from the past. Along these lines, Camila Del Mármol and Ferran Estrada point out that "these certificates work as legitimating devices, adding value and meaning to forms of production that are reminiscent of the natural territory and traditional and vernacular ways of subsistence in which they originated.... The discourses of continuity within an imagined past are key to understanding the production of value (both economic and symbolic) and the legitimatization of current practices of production." 59

This was the case in the "vite ad alberello" application for an intangible cultural heritage of humanity listing, which appealed to the traditional vine-growing methods that had been passed down for generations and whose sweet wine already had a denominazione di origine controllata. ${ }^{60}$ The Valencia certificate of origin operates along the same lines, pursuing initiatives to reinforce experiential value by starting up the Valencia Certificate of Origin Wine Route. ${ }^{61}$ An article published on its website about Terres dels Alforins states the following: "This landscape is not a thing of the past. It remains alive today thanks to all the generations that refused to abandon it-because abandoning it meant losing a reason for living. ... There are no landscapes without hard-working men and women, without the footprints they left along the way. And we can only preserve them if we show respect for their memory." 62

In addition, as is apparent in the last paragraph, the landscape also becomes an important heritage asset. The Champagne proposal stemmed from the association with the "Champagne Landscape," created in 2008 with the aim of submitting a World Heritage application. ${ }^{63}$ In both cases, the narrative is similar. The landscape highlights the connection between the past and the present in a continuum of sorts in which memory and heritage are evident. In the article, the author describes how the vineyards become a marker to give a rural area added cultural value, even going to the extent of stating that they are not part of the past but, rather, of the present. The locations, which are both objects and subjects of heritagization, are presented as bearers of knowledge and vehicles of memory.

In the last few decades, the landscape has drawn the attention of a variety of disciplines and public policies; one example is the Paisajes turísticos valencianos (Valencian Tourist Landscapes) project conducted by the University of Valencia and the Valencian Institute of Tourism Technologies. ${ }^{64}$ Terres dels Alforins is included in the agricultural landscapes category, claiming that "the first existing record of the practice of wine-growing in this area dates back to the Iberian settlement of La Bastida de Les Alcusses, two thousand four hundred years ago. Remains of grapes, tools used for the grape harvest, and a variety of crockery items for drinking wine offer clear evidence that the local Iberian culture had already engaged in this agricultural practice." ${ }^{65}$ This association of Iberian culture and the Mediterranean landscape has been a key element in revitalizing the area.

\footnotetext{
${ }^{58}$ Del Mármol 2017; Parga-Dans and Alonso 2017; Bortolotto and Ubertazzi 2018.

${ }^{59}$ Del Mármol and Estrada 2018, 231.

${ }^{60}$ Broude 2018. For this author, "[t] his example reflects the ambivalence of ICH safeguarding" because it opens up practices to commercialization yet also warrants their safeguarding (423).

61 "Ruta vino DO Valencia," Denominación de Origen Valencia, http://www.dovalencia.info/ruta-vino-do-valencia/ (accessed 8 March 2021).

62 “Una bellísima tierra," Denominación de Origen Valencia, http://www.dovalencia.info/una-bellisima-tierra/ (accessed 8 March 2021).

${ }^{63}$ Thuriot 2019, 135.

${ }^{64}$ Hermosilla 2017.

65 “Universitat de València," Paisajes Valencianos, http://paisajesturisticosvalencianos.com/proyecto/ (accessed 8 March 2021).
} 
Therefore, it is hardly surprising that two wineries with a Moixent certificate of origin have reinforced their links with the past by using the Iberian world as their trademark; both have included it in their brand. Celler del Roure is the foremost example. Its prime location at the gates of La Bastida has served as a claim through metonymic contamination. The foundation of the winery in 1996 coincides with the construction efforts aimed at promoting the site and improving its access. These winemakers have always emphasized origins, history, heritage, and emotions. In several interviews published in the media, they have persuasively reinforced this narrative. Headlines such as "Stories about Wine, Told among Wood and Clay," 66 "Celler del Roure: A Journey into the Valencian Emotional Heritage," 67 or "Celler del Roure: In the Beginning There Was Clay, for Wine as Well" ${ }^{68}$ are indicative of their quest. In addition, they have made efforts to revive the past, recovering a seventeenthcentury underground winery (Bodega Fonda) with over 40 buried clay vessels and reinstating ancient production methods, such as the use of clay instead of wood for their wine barrels.

Celler del Roure's calling card is simple but effective: they are the past in the present. In an interview, one of the owners stated: "We know there are people who are willing to pay a premium for authenticity, and we want them to be satisfied." Authenticity is associated with the past and with tradition. "Paying for authenticity" masterfully encapsulates the new market demand. In the strategy pursued by the winemakers, supported by enological marketing and the wine brand, there is a convergence that pairs history and tradition with advanced technology. In their interviews with the media, they have always highlighted their focus on the past and their commitment to research, linking not only the past with the present but also with the future. The headline of an article about the winery leaves no room for doubt: "An Age-Old Future." For Celler del Roure, the new market demands are crystal clear: "Our industry needs more agronomists, more enologists, more salespeople and more wine ideologues." 69

The winery has also strengthened its ties to the Iberian world by participating in several editions of the La Bastida Open Days; occasionally, the Terres dels Alforins brand has also been involved, as has the Moixent cooperative in recent years. These events have been held yearly since 2008, with increasingly successful attendance. ${ }^{70}$ Under the slogan "Experience a Weekend with the Iberians," offerings include tours with reenactments, workshops, and craft demonstrations. On certain years, the winery has organized visits to witness the artisanal winemaking process, which, in a sense, is validated by the context of a recreation of the Iberian past. Local restauranteurs also participate, offering "Iberian menus," for which the Prehistory Museum of Valencia provides rough guidelines; according to a staff member, these are simply based on the local cuisine, discarding ingredients of American origin such as tomatoes and potatoes. In our field notes, we recorded how these events were perceived by visitors and local residents. What visitors valued most was experiencing the past: "being a part of history," "taking a pleasant, timeless walk," or "you can imagine you were living back then." For the locals, revalorizing the area through the past was the key

\footnotetext{
${ }^{66}$ V. Morcillo, "Historias de vino narradas entre madera y barro," Levante EMV, 23 March 2017, https:// www.levante-emv.com/vinos/2017/03/23/historias-vino-narradas-madera-barro/1544766.html (accessed 8 March 2021).

${ }^{67}$ Eugenio Viñas, “Celler del Roure: viaje al patrimonio valenciano de las emociones," CulturPlaza, 2016, https:// valenciaplaza.com/celler-del-roure-viaje-al-patrimonio-valenciano-de-las-emociones (accessed 8 March 2021).

68 "Celler del Roure: en el principio fue el barro, también para el vino," Economía, vol. 3, 18 March 2017, https:// economia3.com/2017/03/18/100002-celler-del-roure-en-el-principio-fue-el-barro-tambien-para-el-vino/ (accessed 8 March 2021).

${ }^{69}$ Vicente Lladró, “Ideólogos del vino," Las Provincias, 2008, https://www.lasprovincias.es/valencia/20080413/ euros/ideologos-vino-20080413.html?ref=https\%3A\%2F\%2Fwww.google.com\%2F (accessed 8 March 2021).

${ }^{70}$ Fortea and Ripollés 2011.
} 
point: "it promotes Moixent's ancient history," "it gives the village higher visibility and gets people to talk about it," or "[it] allows us to be associated with an interesting, rich, unknown or scarcely known past."

In Moixent, the San Pedro Apóstol cooperative launched the Clos de la Vall brand in 2009, with the Moixent Warrior as its logo. Since then, it has launched other wines, all of which display the same brand. But we would also like to highlight their young wines, named "Moixaranga," not only because of the choice of the name but also because of the label's design. Moixaranga, Muixeranga, or Ball de Valencians are all names for a series of traditional dances that culminate with human towers; they are typical of some areas of Valencia and historically spread to other areas within Spain such as Catalonia and Aragon. In 2011, UNESCO gave an ICH listing to the Festivity of La Mare de Déu de la Salut (in Algemesí, Valencia), in which these dances are the central element. ${ }^{71}$ The name chosen for the wine refers to this tradition and plays with the name of the village; Moixent has the same first four letters as Moixaranga. Its label is sketched with unusual writing: despite using the Latin alphabet, the characters are displayed in an almost hieroglyphical way. One can even glean the occasional Iberian symbol aside from the image of the warrior, along with other colorful elements that have a festive quality. This cooperative also manages an oil press, and, in 2014, it launched a virgin olive oil with a certificate of origin under the name of Pagos del Guerrer. Again, the name and the label emphasized an Iberian past: the image of the figure, and the name of the oil-"Guerrer" (warrior)-highlighted this association. At the product launch, the cooperative referred to "tradition, modernity, and artisanal tradition," just as Celler del Roure had done earlier on.

Therefore, we can see how in Moixent the Iberian past has been transformed into a warranty of authenticity, validated by the past and by tradition. Authenticity and craftsmanship, as opposed to industrialization and standardization, converge to connect with values and attachments that feed the consumer's imagination. And the consumer's interest goes beyond the product itself, tying into a philosophy and a way of life. ${ }^{72}$ In addition to all of this, we have the food heritagization process, particularly following UNESCO's activation of ICH in 2006, after the 2003 Convention for the Safeguarding of Intangible Cultural Heritage. ${ }^{73}$ The Mediterranean Diet, included in the ICH list in 2010 and extended in 2013, provides the framework for the products, endowing them with higher value. Within its meta-cultural and ideological context, we wish to highlight the mythical wheat-grape-olive trilogy. ${ }^{74}$ All three of them are present in Moixent: the first, through the Alforins (granary) brand, and the second and third, through wine and oil, are all connected to a past that is both enhanced and efficiently defined.

Thus, heritage stratification-different heritage layers that overlap in a single place (culture, landscape, enology, and so on)-can be identified with different types of activation and protection measures. Some are salient enough to act as landmarks for the area, as is the case with Iberian culture. Others are less obvious, acting implicitly in the construction of narratives, as in the case of Terres dels Alforins, where everything from the landscape to the Mediterranean diet come into play. It is interesting to note that Terres dels Alforins is sometimes referred to as "the Valencian Tuscany." The comparison with one of the areas with the richest heritage in Italy is an indication of the discourse strategies that wrap the place in a cloak of heritage. The mention of this prestigious brand is used as a claim and a measure of the local heritage value.

\footnotetext{
${ }^{71}$ The origin of these dances is a controversial subject that we will not discuss here, although it is interesting to note that in some cases there have been attempts to link them to the Iberian-Roman past.

${ }^{72}$ Ortiz 2001.

${ }^{73}$ Convention for the Safeguarding of Intangible Cultural Heritage, 17 October 2003, 2368 UNTS 1.

${ }^{74}$ Medina 2018, 8.
} 
A prime example of how fruitful the heritage confluence of wine, landscape, and Iberian culture has been in Moixent is that in 2009, faced with the threat of a large landfill being built in the area of Les Alcusses to handle the waste from all the neighboring counties (with a joint population of about 300,000 ), the different heritage stakeholders joined forces to avert what they considered to be an unprecedented potential disaster for the municipality and its surroundings. ${ }^{75}$ Although the main reason given was the threat of environmental impact, the two other arguments against the major project were the winemaking industry and the archaeological site. These were at the center of a narrative that placed the heritage landmarks on the front line of the conflict: first, production of a wine with a Valencia certification of origin, made by wineries that were market leaders and respectful of traditions, and, second, La Bastida, presented as the home of the Moixent Warrior. According to one of the winemakers who produced Terres dels Alforins, the brand that achieved the highest profile in the media during this conflict, "the landfill would be a dagger in the heart of Valencian wines." ${ }^{76}$ One of the strategies they pursued was to try to have the area declared a natural municipal site of the Valencian community. The alliance of heritage formulas and economic interests not only managed to stop the waste facility from being built but also consolidated Moixent's role as a major inland tourist destination and reinforced the protection of its landscape.

\section{Discussion}

The notions of the past, authenticity, and tradition envelop the Iberians in a cloak that positions them as a powerful brand and a heritage-marketing resource for rural development. Local identification with Iberian culture is particularly powerful in those towns with a noteworthy, easily recognized Iberian past, as is the case with Moixent. In other cases, the activation of cultural strategies and tourism brands, such as the Iberian Route, has given visibility to this heritage. The tendency to use the Iberian heritage as a claim is based on institutional recognition (BIC), supported by archaeology and the prestige acquired through its icons and toponyms. The narratives set forth about the Iberians, based on a variety of practices and rhetoric, have redefined their image, playing an important role in the representations of local identity and providing an outstanding resource for rural development. Their uses are many and contribute to creating heritage stratifications. If we focus on wine, viewing it as a socio-economic and cultural artifact, it is embedded in the landscape (land, tradition, memory) and in Iberian culture (origin, history, past) through different heritage layers that provide locals with differentiation and authenticity. This process manages to endow a place-in this case, Terres dels Alforins-with a strong enough appeal to enter the tourism market.

Today, cultural tourism has become the leading segment in the global tourism demand; as some authors note, "cultural heritage is one of the most pervasive tourism products throughout the world," future." 78 Given this situation, there are obvious benefits to activating heritage assets in rural areas, by reorienting their production strategies to adapt to the new marketplace. However, as Tomer Broude points out in reference to ICH-although it would also apply to any other heritage category-there is an ambivalence between protection/safeguarding and

\footnotetext{
${ }^{75}$ Paco Cerdà, “Moixent grita 'no' al vertedero," Levante EMV, 3 September 2009, https://www.levante-emv. com/comarcas/2009/03/09/moixent-grita-vertedero/564490.html (accessed 8 March 2021).

76 “Miles de personas, contra el vertedero de Les Alcusses," El País, 3 September 2009, https://elpais.com/diario/ 2009/03/09/cvalenciana/1236629887_850215.html (accessed 8 March 2021).

77 Timothy 2018, 179.

${ }^{78}$ World Tourism Organization 2018, 12.
} 
a dependency on commercialization. To some degree, the contradiction seems impossible to resolve. Today, heritage conservation faces the challenge of its own commercialization and trivialization. The process of offering experiences can turn sites into theme parks, contributing to the exact opposite of what was originally intended. The potential and exponential increase in visitors leads to more deterioration than conservation linked to interpreting heritage assets. Certifications of origin, viewed as heritage vehicles, can be analyzed similarly. On the one hand, they can contribute to preserving local production practices; however, by introducing a new brand, they can enter commodification networks while concealing market imperatives behind the heritage rhetoric.

Hence, for example, the rise of developments such as the terroirista movement in Spain, which seek to highlight sustainability, redistribution, and rural identity in opposition to industrial winemaking. ${ }^{79}$ Much still remains to be done along these lines. The pairing of tourism and heritage ought to pose at least two questions: whether, as Hølleland and Skrede claim, "experts should rather expose and explore their normative commitment to making heritage practices socially inclusive" 80 and whether it is possible to contribute toward achieving participatory governance of heritage beyond its cosmetic use. ${ }^{81}$

\section{Bibliography}

Alcaraz, Gemma, and Francisco Medina. 2019. “Adapting Marketing Strategies: A Linguistic Analysis of Wine Advertising in Spain, 1970-2010." Journal of Evolutionary Studies in Business 4, no. 1: 109-41.

Alonso, Pablo, and Eva Parga-Dans. 2019. "La vuelta al terroir: el despertar de la cultura del vino en España." Revista Iberoamericana de Viticultura, Agroindustria y Ruralidad 6, no. 17: 62-89.

Anderson, Benedict. 1983. Imagined Communities: Reflections on the Origins and Spread of Capitalism. London: Verso.

Angé, Oliva, and David Berliner, eds. 2016. Anthropology and Nostalgia. New York: Berghahn.

Aranegui, Carmen. 2012. Los iberos ayer y hoy. Arqueologías y culturas. Madrid: Marcial Pons.

Arce, Javier, and Ricardo Olmos, eds. 1991. Historiografía de la Arqueología y de la Historia Antigua en España (siglos XVIIIXX). Madrid: Instituto de Conservación y Restauración de Bienes Culturales.

Archilés, Ferran. 2006. “'Hacer región es hacer patria.' La región en el imaginario de la nación española de la Restauración.” Ayer 64, no. 41: 121-47.

Azuar, Rafael. 2013. Museos, arqueología, democracia y crisis. Gijón: Trea.

Baram, Uzi, and Rowan Yorke. 2004. "Archaeology after Nationalism: Globalization and the Consumption of the Past." In Marketing Heritage: Archaeology and the Consumption of the Past, edited by Y. Rowan and U. Baram, 3-23. Walnut Creek, CA: AltaMira.

Bauman, Zygmund. 1991. Modernidad y ambivalencia. Barcelona: Anthropos.

Bauman, Zygmund. 2017. Retrotopia. Cambridge, UK: Polity Press.

Beck, Ulrich, and Elisabeth Beck-Gernsheim. 2003. Individualization: Institutionalized Individualism and Its Social and Political Consequences. London: Sage Publications.

Bendix, Regina F. 2009. "Heritage between Economy and Politics: An Assessment from the Perspective of Cultural Anthropology." In Intangible Heritage, edited by L. Smith and N. Akagawa, 253-69. London: Routledge.

Benjamin, Walter. 2007. "The Work of Art in the Age of Mechanical Reproduction." In Illuminations: Essays and Reflections, edited by W. Benjamin, H. Zohn, and H. Arendt, 1-26. New York: Schocken Books.

Berger, Peter L., and Thomas Luckmann. 1995. Modernity, Pluralism and the Crisis of Meaning. Gütersloh: Bertelsmann Foundation Publishers.

Boltanski, Luc, and Chiapello, Ève. 2002. El nuevo espíritu del capitalismo. Madrid: Akal.

Bonet, Helena, and Jaime Vives-Ferrándiz, eds. 2011. La Bastida de les Alcusses: 1928-2010. Valencia: Museu de Prehistòria de València.

Bonet, Helena, Jaime Vives-Ferrándiz, and Isabel Caruana. 2005. "La Bastida de les Alcusses (Moixent, Valencia). Investigación y musealización.” In La Contestania Ibérica, treinta años después, edited by I. Grau, F. Sala-Sallés, and L. Abad, 267-80. Alicante: Universidad de Alicante.

\footnotetext{
79 Alonso and Parga-Dans 2019, 84.

${ }^{80}$ Hølleland and Skrede 2019, 9.

${ }^{81}$ Sánchez-Carretero et al. 2019.
} 
Bortolotto, Chiara, and Benedetta Ubertazzi. 2018. "Editorial: Foodways as Intangible Cultural Heritage." International Journal of Cultural Property 25, no. 4: 409-18.

Boym, Svetlana. 2001. The Future of Nostalgia. New York: Basic Books.

Broude, Tomer. 2018. "Mapping the Potential Interactions between UNESCO's Intangible Cultural Heritage Regime and World Trade Law." International Journal of Cultural Property 25, no. 4: 419-48.

Cruz Andreotti, Gonzalo. 2002. "Iberia e iberos en las fuentes histórico-geográficas griegas: una propuesta de análisis.” Mainake 24: 153-80.

Davallon, Jean. 2010. “The Game of Heritagization.” In Constructing Cultural and Natural Heritage, edited by X. Roigé and J. Frigolé, 27-38. Girona: Institut Català de Recerca en Patrimoni Cultural.

Del Mármol, Camila. 2017. "The Quest for a Traditional Style: Architecture and Heritage Processes in a Pyrenean Valley." International Journal of Heritage Studies 23, no. 10: 946-60.

Del Mármol, Camila, Gemma Celigueta, and Ismael Vaccaro. 2018. "Socio-economic Transitions and Everyday Life Changes in the Rural World: Pyrenean Households and Their Contemporary Economic History." Journal of Agrarian Change 18, no. 3: 677-93.

Del Mármol, Camila, and Ferran Estrada. 2018. "Naturalizing Culture in the Pyrenees: Heritage Processes in Rural Contexts." In Decolonizing Heritage: Natures, Cultures and the Asymmetries of Memory, edited by A. Arregui, G. Mackenthun, and S. Wodianka, 219-36. Münster: Waxmann Verlag.

Del Mármol, Camila, and Beatriz Santamarina. 2019. "Seeking Authenticity: Heritage and Value within the Intangible Economy." Journal of Mediterranean Studies 28, no. 2: 117-32.

Díaz-Andreu, Margarita. 1995. "Archaeology and Nationalism in Spain." In Nationalism, Politics and the Practice of Archaeology, edited by P. L. Kohl and C. Fawcett, 39-56. Cambridge, UK: Cambridge University Press.

Egloff, Brian. 2006. "Introduction." In of the Past, for the Future: Integrating Archaeology and Conservation. Part IV: Finding Common Ground: The Role of Stakeholders in Decision Making. Proceedings of the Conservation Theme at the 5th World Archaeological Congress, edited by N. Agnew and J. Bridgland, 85-86. Los Angeles: Getty Conservation Institute.

Espeso-Molinero, Pilar. 2016. "Quiero ver un lacandón con arco": Diálogo de saberes en el turismo indígena lacandón. PhD dissertation, Universidad de Alicante, Alicante.

Espeso-Molinero, Pilar. 2019. “Tendencias del turismo cultural.” Revista Pasos 17, no S6: 1101-12.

Fernández, Julio. 2019. "Las etiquetas de las botellas de vino: su valor como recurso comercial y como expresión del paisaje vitivinícola.” Boletín de la Asociación de Geógrafos Españoles 81, no. 2759: 1-33.

Ferrer, Carles, Consuelo Mata, and Jaime Vives-Ferrándiz. 2007. "La ruta Ibérica Valenciana. Una propuesta de desarrollo.” In Fourth Congreso Internacional sobre Musealización de Xacementos Arqueolóxicos, edited by P. Varela, 337-43. Santiago de Compostela: Xunta de Galicia.

Ferrer, Carles, and Jaime Vives-Ferrándiz. 2014. “Patrimonio arqueológico y turismo. Unas reflexiones finales.” In El pasado en su lugar. Patrimonio, arqueología, desarrollo y turismo, edited by J. Vives Ferrándiz and C. Ferrer, 177-89. Valencia: Museu de Prehistòria de València.

Fortea, Laura, and Eva Ripollés. 2011. "La didáctica en los espacios patrimoniales. Talleres de experimentación y jornadas de visita." In La Bastida de les Alcusses 1928-2010, edited by H. Bonet and J. Vives-Ferrándiz, 274-313. Valencia: Museu de Prehistòria de València.

Frigolé, Joan. 2007. "Los modelos de lo rústico, lo salvaje y lo silvestre y la identidad de una valle del entorno de Cadí (Alt Urgell).” In Ecología política de los Pirineos. Estado, Historia y Paisaje, edited by I. Vaccaro and O. Beltran, 157-71. Barcelona: Garsineu Edicions.

Frigolé, Joan. 2010. "Patrimonialization and the Mercantilization of the Authentic: Two Fundamental Strategies in a Tertiary Economy." In Constructing Cultural and Natural Heritage: Parks, Museums and Rural Heritage, edited by X. Roigé and J. Frigolé, 27-38. Girona: Institut Català de Recerca en Patrimoni Cultural.

Frigolé, Joan. 2014. "Retóricas de la autenticidad en el capitalismo avanzado.” Endoxa 33: 37-60.

Giddens, Anthony. 1990. The Consequences of Modernity. Cambridge, UK: Polity Press.

Gómez, Eloy. 2016. "El patrimonio etnográfico: de patrimonio despreciado a patrimonio valioso." In Patrimonio olvidado, patrimonio recuperado, edited by M. Cisneros and V. Cuñat, 45-74. Cantabria: Universidad de Cantabria.

González, Susana, and Carmen Rueda. 2010. Imágenes de los iberos: comunicar sin palabras en las sociedades de la antigua Iberia. Barcelona: Crítica.

Hall, Stuart. 2010. “Identidad cultural y diaspora." In Sin garantías: Trayectorias y problemáticas en estudios culturales, edited by E. Restrepo, C. Walsh, and V. Vich, 349-61. Popoyán, Spain: Envión Editores.

Hamilakis, Yannis. 2003. "Lives in Ruins: Antiquities and National Imagination in Modern Greece." In The Politics of Archaeology and Identity in a Global Context, edited by S. Kane, 51-78. Boston: Archaeological Institute of America.

Haskel, Jonathan, and Stian Westlake. 2017. Capitalism without Capital: The Rise of the Intangible Economy. Princeton, NJ: Princeton University Press.

Heinich, N. 2009. La fabrique du patrimoine. De la cathédrale à la petite cuillère. Paris: Maison des Sciences de l'Homme. Hermosilla, Jorge. 2017. "Paisajes turísticos valencianos, valiosos, valorados: un proyecto estratégico de desarrollo territorial para la Comunitat Valenciana." Papers de Turisme 60: 91-93. 
Herzfeld, Michael. 2005. Cultural Intimacy: Social Poetics in the Nation-state. London: Routledge.

Hobsbawm, Eric, and Terence Ranger, eds. 1983. The Invention of Tradition. Cambridge, UK: Cambridge University Press. Hølleland, Herdis, and Joar Skrede. 2019. "What's Wrong with Heritage Experts? An Interdisciplinary Discussion of Experts and Expertise in Heritage Studies." International Journal of Heritage Studies 25: 825-36.

Holtorf, Cornelius. 2013. "On Pastness: A Reconsideration of Materiality in Archaeological Object Authenticity." Anthropological Quarterly 86, no. 2: 427-43.

Ilak, Anita Silvana, Ana Težak Damijanić, and Zdravko Šergo. 2019. “The Wine Tourism Terroir: Experiences from Istria." Tourism in Southern and Eastern Europe: Creating Innovative Tourism Experiences: The Way to Extend the Tourist Season 5: 319-33.

Jeudy, Henri-Pierre. 2001. La Machinerie patrimoniale. Paris: Sens \& Tonka.

Jiménez-Esquinas, Guadalupe, and Cristina Sánchez-Carretero. 2018. "Who Owns the Name of a Place? On Place Branding and Logics in Two Villages in Galicia, Spain.” Tourist Studies 18, no. 1: 3-20.

Jokilehto, Jukka. 2006. "Considerations on Authenticity and Integrity in World Heritage Context." City \& Time 2, no. 1:1-16.

Korstanje, Maximiliano E. 2012. "Reconsidering Cultural Tourism: An Anthropologist's Perspective." Journal of Heritage Tourism 7, no. 2: 179-84.

Korstanje, Maximiliano E. 2019. "Lo no-patrimoniable es invisible a la vista: la obsesión moderna por el Patrimonio Turístico.” El periplo sustentable 36: 432-46.

Kristiansen, Kristian. 1992. "The Strength of the Past and Its Great Might: An Essay on the Use of the Past." Journal of European Archaeology 1: 3-32.

Lowenthal, David. 1985. The Past Is a Foreign Country. Cambridge, UK: Cambridge University Press.

MacCannell, Dean. 1999. The Tourist: A New Theory of the Leisure Class. Berkeley: University of California Press.

MacDonald, Sharon. 2013. Memorylands: Heritage and Identity in Europe Today. London: Routledge.

Marlowe, Byron, and Sojung Lee. 2018. "Conceptualizing Terroir Wine Tourism." Tourism Review International 22, no. 2: $143-51$.

Mata, Consuelo, and Tono Vizcaíno. 2013. "Patrimoni arqueològic i desenvolupament local: les jornades de portes obertes de Kelin (Caudete de las Fuentes, València)." In Turisme cultural, desenvolupament territorial i sostenibilitat, edited by Vicerectorat de Participació i Projecció Territorial, 172-81. Valencia: Universitat de València.

Medina, Francisco Xavier. 2018. "La construcción del patrimonio cultural inmaterial de carácter alimentario y sus retos en el área mediterránea: el caso de la Dieta Mediterránea.” Revista Iberoamericana de Viticultura, Agroindustria y Ruralidad 5, no. 14: 6-23.

Melotti, Marxiano. 2017. "Vino, archeologia e turismo culturale." In In viaggio per cibo e vino. Esperienze creative a confronto, edited by R. Garibaldi, 85-126. Vol. 2. Rome: Aracne.

Meskell, Lynn. 2014. "States of Conservation: Protection, Politics, and Pacting within UNESCO's World Heritage Committee.” Anthropological Quarterly 87, no. 1: 217-43.

Molinero, Fernando, and Cayetano Cascos. 2017. "La revitalización del patrimonio territorial por la explotación vitícola en La Ribera del Duero: viticultura y paisaje.” In Naturaleza, territorio y ciudad en un mundo global, 2128-37. Madrid: Asociación de Geógrafos Españoles.

Nogué, Joan, and Jordi San Eugenio. 2017. "The Visual Landscape's Contribution to Generating Territorial Brands." Boletin de la Asociación de Geógrafos Españoles 74: 143-60.

Ortiz, Carmen. 2001. "Consumint tradició: elements patrimonials i locals en la publicitat alimentària." Revista d'Etnologia de Catalunya 19: 72-85.

Parga-Dans, Eva, and Pablo Alonso. 2017. "Marketing Quality in the Food Sector: Towards a Critical Engagement with the 'Quality Turn' in Wine." Geoforum 85: 5-8.

Pérez, Clara, and Paula Jardón. 2011. "La dramatización como herramienta de interpretación del patrimonio arqueológico." Quaderns 3: 233-38.

Picard, David, Catarina Nascimento, and Tristan Loloum. 2018. "Wine Magic: Consumer Culture, Tourism, and Terroir." Journal of Anthropological Research 74, no. 4: 526-40.

Poulot, Dominique. 2006. Une histoire du patrimoine en Occident, XVIII-XIX siècle. Du monuments aux valeurs. Paris: Presses Universitaires de France.

Richards, Greg. 2000. "Tourism and the World of Culture and Heritage." Tourism Recreation Research 25, no. 1: 9-17.

Richards, Greg. 2014. Tourism Trends: The Convergence of Culture and Tourism. Breda, Netherlands: Academy for Leisure NHTV University of Applied Sciences.

Richards, Greg. 2019. "Culture and Tourism: Natural Partners or Reluctant Bedfellows? A Perspective Paper." Tourism Review 75, no. 1: 232-34.

Ripollés, Eva, Laura Fortea, Carles Ferrer, and J. Vives-Ferrándiz. 2016. "Contar contigo. Perspectivas de género en el proyecto de difusión patrimonial de la Bastida de les Alcusses (Moixent, Valencia)." Boletín del Instituto Andaluz de Patrimonio Histórico 89: 159-62. 
Rivière, Aurora. 2000. "Envejecimiento del presente y dramatización del pasado: una aproximación a las síntesis históricas de las Comunidades Autónomas españolas (1975-1995).” In La gestión de la memoria, edited by J. S. Pérez Garzón, 161-219. Barcelona: Crítica.

Roigé, Xavier, and Joan Frigolé, eds. 2010. Constructing Cultural and Natural Heritage: Parks, Museums and Rural Heritage. Girona: Institut Català de Recerca en Patrimoni Cultural.

Ruiz, Arturo, and Manuel Molinos. 1998. Archaeology of the Iberians. Cambridge, UK: Cambridge University Press.

Ruiz, Arturo, Alberto Sánchez, and Juan Bellón. 2002. "The History of Iberian Archaeology: One Archaeology for Two Spains." Antiquity 76, no. 291: 184-90.

Sánchez-Carretero, Cristina, José Muñoz, Ana Ruiz, and Joan Roura, eds. 2019. El imperativo de la participación en la gestión patrimonial. Madrid: Consejo Superior de Investigaciones Científicas.

Santamarina, Beatriz, and Oriol Beltran. 2016. "Heritage and Knowledge: Apparatus, Logic and Strategies in the Formation of Heritage." Anthropological Forum 26, no. 4: 397-414.

Santamarina, Beatriz, and Camila Del Mármol. 2020. "'Para Algo que era Nuestro ... Ahora es de Toda la Humanidad': El Patrimonio Mundial como Expresión de Conflictos." Chungará-Revista de Antropología Chilena 52, no. 1: 161-73.

Santamarina, Beatriz, and Albert Moncusí. 2015. "El mercado de la autenticidad: las nuevas ficciones patrimoniales." Revista de Occidente 440-41: 93-112.

Schnitzler, Bernardette, and Françoise Schnitzler, eds. 2006. Archéopub. La survie de l'Antiquité dans les objets publicitaires. Strasbourg: Musée Archéologique de Strasbourg.

Scott, Allen. 2014. "Beyond the Creative City: Cognitive-Cultural Capitalism and the New Urbanism." Regional Studies 48, no. 4: 565-78.

Smith, Laurajane. 2004. Archaeological Theory and the Politics of Cultural Heritage. London: Routledge.

Spooner, Brian. 1988. "Weavers and Dealers: The Authenticity of an Oriental Carpet." In The Social Life of Things: Commodities in Cultural Perspective, edited by A. Appadurai, 195-235. Cambridge, UK: Cambridge University Press.

Thuriot, Fabrice. 2019. "Effects of the World Heritage Label in Champagne Region." In Wine Tourism Destination Management and Marketing: Theory and Cases, edited by M. Sigala and R. N. S. Robinson, 135-38. London: Palgrave Macmillan.

Timothy, Dallen J. 2011. Cultural Heritage and Tourism: An Introduction. Bristol: Channel View Publications.

Timothy, Dallen J. 2018. "Making Sense of Heritage Tourism: Research Trends in a Maturing Field of Study.” Tourism Management Perspectives 25: 177-80.

Vives-Ferrándiz, Jaime. 2006. "Un plomo escrito y un jinete de bronce. Percepciones y usos de dos piezas de la Bastida de les Alcusses." In Arqueología en Blanco y Negro. La labor del SIP 1927-1950, edited by H. Bonet, M. J. De Pedro, A. Molina, and C. Ferrer, 141-48. Valencia: Museu de Prehistòria de València.

Vizcaíno, Tono. 2016a. "Roma no es suficiente. La invención del origen ibérico en el relato identitario de Valencia." Arkeogazte 6: 55-73.

Vizcaíno, Tono. 2016b. "Una dama para la región. La Dama de Elche como símbolo del regionalismo valenciano." ArqueoWeb 17: 163-81.

Vizcaíno, Tono. 2018. A la recerca dels orígens. El passat iber en l'imaginari collectiu valencià. Valencia: Institució Alfons el Magnànim.

World Tourism Organization. 2018. Tourism and Cultural Synergies. Madrid: World Tourism Organization.

World Tourism Organization. 2019. World Tourism Barometer. Madrid: World Tourism Organization.

Wulff, Fernando. 2003. Las esencias patrias. Historiografía e Historia Antigua en la construcción de la identidad española (siglos XVI-XX). Barcelona: Crítica.

Yalouri, Eleana. 2014. "In the Spirit of Matter: Reconnecting to Antiquity in the Greek Present." In Re-imagining the Past: Antiquity and Modern Greek Culture, edited by D. Tziovas, 165-85. Oxford: Oxford University Press.

Cite this article: Santamarina, Beatriz, and Tono Vizcaíno. 2021. "Consuming the past into the present: The case of the Iberians (Valencia, Spain).” International Journal of Cultural Property 28, no. 1: 159-174. https://doi.org/10.1017/ S0940739120000302 